\title{
Religion and Family Relational Health: An Overview and Conceptual Model
}

Loren Marks

Brigham Young University - Provo, loren_marks@byu.edu

Follow this and additional works at: https://scholarsarchive.byu.edu/facpub

Part of the Other Social and Behavioral Sciences Commons

\section{Original Publication Citation}

Marks, L. D. (2006). Religion and family relational health: An overview and conceptual model. Journal of Religion and Health, 45, 603-618.

\section{BYU ScholarsArchive Citation}

Marks, Loren, "Religion and Family Relational Health: An Overview and Conceptual Model" (2006). Faculty Publications. 4900.

https://scholarsarchive.byu.edu/facpub/4900 


\title{
Religion and Family Relational Health: An Over- view and Conceptual Model
}

\author{
LOREN MARKS
}

ABSTRACT: This paper presents a review of research addressing religion and family relational health. Strengths of the extant data include the correlation of three dimensions of religious experience (religious practices, religious beliefs, and religious community) with certain aspects of mother-child, father-child, and marital relationships and specific connections between the three dimensions of religious experience and family relationships are identified. Key weaknesses in the research at present include a paucity of research examining the hows, whys, and processes involved behind identified religion-family correlations and a lack of data on non-nuclear families, families of color, interfaith families, and non-Christian religions including Judaism and Islam. Implications for clinical practice and recommendations for future research are offered.

KEY WORDS: religion; spirituality; parenting; marriage; health.

Historically, influential social and behavioral scientists have tended to malign religion in their conceptual writings. Religion was, to Marx, "the opium of the people” (cf. Marx \& Engels, 1964; Stark \& Bainbridge, 1996). Ellis (1986) referred to religion as a form of psychopathology. Freud categorically defined religion as the universal obsessional neurosis in his early work and-as Stark and Bainbridge (1996) have pointed out-Freud later called religion "an 'intoxicant,' 'a poison,' and 'childishness to be overcome'-all on one page" (see Freud, 1927, p. 88).

Over the past decade, however, a wave of empirical research has examined religion and social science has reached a point where some initial bearings on the religion-family linkage can be taken. At present, the connection between

\footnotetext{
Loren Marks is an Assistant Professor of Family, Child, and Consumer Sciences in the School of Human Ecology at Louisiana State University. He and his research collaborator, David Dollahite of BYU, have conducted extensive qualitative research with over 125 Christian, Jewish, Mormon, and Muslim families to examine the interfaces between religion, individual development, and family relationships. Correspondence to Loren Marks, School of Human Ecology, Louisiana State University, Baton Rouge, LA, 70803, USA; e-mail: lorenm@lsu.edu.
} 
religion and families is receiving more rigorous, balanced, and comprehensive treatment than ever before, including foci on healthy and unhealthy aspects of religion (for recent reviews see Christiano, 2000; Dollahite, Marks, \& Goodman, 2004; Koenig, McCullough, \& Larson, 2001; Mahoney, Pargement, Tarakeshwar, \& Swank, 2001; Marks, 2005). The objective of this paper is to offer an overview of research findings from this newly burgeoning area of family studies, while identifying some key strengths and weaknesses of this research.

\section{Religion-Family research: Some initial considerations}

In the empirical literature on religion and family relationships, "religion" and "religiosity" have often been measured with minimal breadth and depth. Specifically, $83 \%$ of the studies linking religion with marriage and parenting during the 1980s and 1990s relied on one or two items to assess family members' religiosity (Mahoney et al., 2001). These limitations in conceptualization and measurement raise questions regarding how adequately "religion" is operationalized in many extant studies. However, even though "measurement of spiritual/religious constructs...has usually been poor in quality" (Miller \& Thoresen, 2003, p. 26), the construct of religion has emerged as a statistically significant factor in a myriad of studies (Dollahite et al., 2004). This point seems to indicate that the religion-family connection is of importance, even if research does not yet satisfactorily capture religion or explain the processes at work. In a recent review, Dollahite et al. (2004) conclude that:

while we cannot summarily state that "religiosity" is either good or bad for families, the preponderance of studies point to a positive relationship between religiosity and salutary outcomes in marriage and family relationships.... [However], we reiterate that...the dimension of religiosity (belief, practice, or community)...[must] be considered in assessing the religiosity-family connection with appropriate empirical, conceptual, and contextual sensitivity. (p. 421)

Consistent with this call for a three-dimensional consideration of religion in connection with families, the literature overviewed in this paper will be addressed under the headings of: (a) religious beliefs (beliefs, framings, meanings, and perspectives that are faith-based); (b) religious practices (expressions of faith such as prayer, scripture study, rituals, traditions, or abstinences that are religiously grounded); and (c) religious communities (support, involvement, and relationships rooted in one's congregation or less formal religious community). 
How does religion interface with families?: An overview and conceptual model

The review-based model (Model 1, p. 6) presented here is not intended to be theoretical. It is a heuristic device designed to visually represent how extant data link different dimensions of religion (religious practices, religious beliefs, and religious community) with family relationships. The model presents individuals $(\mathrm{C}=$ child, $\mathrm{M}=$ mother, $\mathrm{F}=$ father) in the context of a nuclear family, reflecting the fact that most research on religion and families examines intact nuclear families (Dollahite et al., 2004). At present, disappointingly little is known about religion in connection with other family forms in spite of the fact that intact, two-parent families are decreasingly modal (Marsiglio, Amato, Day, \& Lamb, 2000). Further, most available data are drawn from white, Christian, same-faith families. In short, present knowledge is constrained by a lack of family or religious diversity - a point to which I will later return. With these limitations of sample and scope noted, however, I offer an overview of what is known.

Religious practices and the marital relationship: Arrow 1A

Key research linking the dimension of religious practices to the father-mother (F-M) marital relationship includes Fiese and Tomcho's (2001) work with a

\section{MODEL 1}

\section{Research connections between religious beliefs, practices, and communities and mother-child, father-child, and marital relationships}

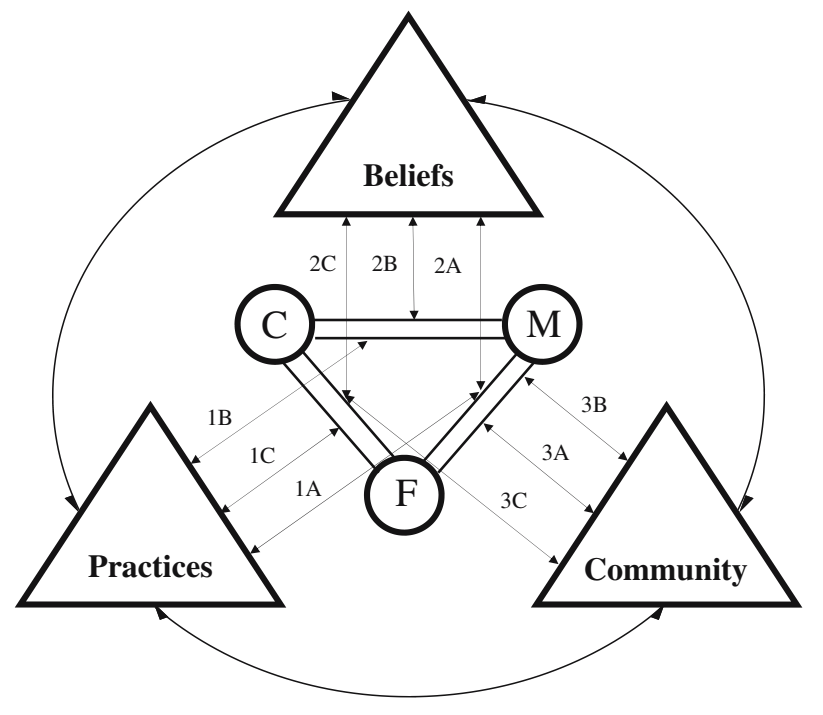


primarily Catholic sample correlating shared, meaningful religious holiday rituals with higher levels of marital satisfaction-although more distal reports of religiousness (e.g., affiliation) were not linked with marital satisfaction in that study. Mahoney et al. (1999) also indicate that proximal measures of religiosity are more significant for the marital relationship than distal reports. Similarly, Lee, Rice, and Gillespie (1997) link home-based family worship with higher marital satisfaction. Even so, the Lee et al. study also found that compulsory family worship may be more detrimental for children than no family worship at all, illustrating the need for research that moves beyond reported frequencies of religious behaviors to an examination of the meanings and processes associated with the practices (cf. Mahoney, Pargament, MurraySwank, \& Murray-Swank, 2003).

Research on Jewish families indicates that certain rituals, including the celebration of the Sabbath (i.e., the lighting of the candles, the Shabbat meal, and sacred prayers and blessings), can serve as family-strengthening practices (Kaufman, 1991). Such rituals seek to prompt a deliberate turning from the mundane to the sacred (e.g., Eliade, 1959), and a renewal of relationships with spouse and children. Marks' (2004) qualitative work also references the familial nature of Jewish ritual while presenting parallel marriage-strengthening practices in highly religious Muslim and Mormon families as well (Dollahite \& Marks, 2005).

Religious practices and the mother-child relationship: Arrow $1 B$ Empirical work that addresses religious practices in connection with the mother-child (M-C) bond includes Boyatzis and Janicki's (2003) mixed-method study (surveys and diaries) that indicates that most Christian mothers frequently engaged in bi-directional communication with their children regarding matters of faith, a practice that has been retrospectively reported to be influential later in children's lives (Wuthnow, 1999).

Other mother-child linkages include Pearce and Axinn's (1998) finding that "various dimensions of family religious life [including religious practices] have enduring effects on mothers' and children's perceptions of the quality of the mother-child relationship" (p. 810). A similar finding is that parallels exist between children's conceptualizations of what God is like (God images) and parent-child interactions and relationships (Vergote, 1980). Research further indicates that kind, loving behavior by parents facilitates the ability of a child to conceive of and believe in a loving God, while hostile parental practices tend to dispel a child's faith in a benevolent supreme being (Vergote, 1980; cf. Dollahite, 1998). Fathers' parenting practices were the primary focus of early research on children's God images but mothers are now studied as well, with research indicating that in some respects "parenting by mothers more than by fathers predicts youths' images of God" (Hertel \& Donahue, 1995, p. 196, emphasis in original). Such findings indicate the importance of including both parents in research on 
the religion-family connection if we are to understand religion's influence in children's lives.

Unfortunately, empirical studies on the religion-mothering connection like Pearce and Axinn (1998) and Hertel and Donahue (1995) are rare, leaving us with little knowledge regarding specific religious practices in the mother-child relational context. In her review of literature on women's religiosity, Ozorak (1996) tentatively reports that

It is premature to generalize...[that women find religion "predominantly satisfying"]; however, recent studies show that the sustaining nature of religious involvement is equally true for African-American women, as well as [for] conservative white Christians...[and] Jews (p. 27, emphasis added).

In a more recent review, encompassing additional work published after Ozorak's review, Koenig et al (2001) emphasize that

Women are more likely to attend religious services, pray privately, say religion is important in their lives and depend on religion as a coping [support]. Thus, it is possible that religious...practices are more deeply ingrained into the social and psychological lives of women and therefore confer greater health benefits (p. 329).

By way of comparison, the guest editors of a 2001 special issue of Journal of Family Psychology addressing religion-family linkages summarized,

On the basis of some of the findings of these articles, it may be that religion, like marriage, has a greater impact on men's behavior and well-being than on women's (Snarey \& Dollahite, 2001, p. 647).

Initially, these two statements may seem contradictory. However, Koenig and colleagues seem to be speaking in terms of across-gender comparison where data clearly indicate that American women, categorically speaking, are significantly more religiously involved than are men. Conversely, Snarey and Dollahite's point that religion may have a greater impact on men's behavior and well-being is drawn from studies that include within-gender comparison (where differences between religious and non-religious men are more pronounced than those between religious and non-religious women). Both statements, when contextualized, are substantiated and relevant in our understanding of families.

\section{Religious practices and the father-child relationship: Arrow $1 C$}

The religion-fathering intersection needs quantitative attention (e.g., King, 2003; Wilcox, 2002), particularly in connection with religious practices. In-depth qualitative studies indicate that some religious practices, including prayer, reportedly strengthen the father-child (F-C) bond for several of the 
fathers in Mormon samples (Dollahite, 2003; Dollahite, Marks, \& Olson, 1998; Marks \& Dollahite, 2001). Recent qualitative work including Christian, Jewish, and Muslim families has revealed that these faiths include practices that reportedly promote a sense of closeness with each other and with God (Dollahite \& Marks, 2005; Marks, 2004). Such practices include saying grace for Protestant Christians, offering novenas (prayers centered on gratitude) for Catholic Christians, family home evening for Latter-day Saint Christians, the Shabbat meal and accompanying ritual for Jewish families, and the Ramadan fast for Muslims. In most cases, these rituals and practices were reportedly meaningful (often deeply or transcendently so) for both fathers and mothers (Dollahite \& Marks, 2005; Marks, 2004).

In other qualitative work with 64 diverse fathers, Palkovitz and Palm (1998) found that fatherhood often prompts men to reassess their religious faith, and that many "become more involved and increase [their] participation in religious practices" after becoming a father (p. 36). This latter finding indicates a reciprocal relationship between family and religious practices and elicits questions regarding the less frequently examined influence of family on religion (Dollahite et al., 2003; Palkovitz, 2002).

In terms of clinical relevance, individual, couple, and family therapy often involves establishing new patterns of behavior and interaction with others. Much of the research that has been conducted on religious practice and ritual focuses on healthy family rituals and positive approaches to coping. The facilitative potential of such activities, whether religiously grounded or not, in promoting well being has not escaped leading family practitioners (e.g., Doherty, 2001, 2002; Imber-Black \& Roberts, 1993; Imber-Black, Roberts, \& Whiting, 1988). I now turn from the behavioral dimension of religious practices to the more cognitive dimension of religious beliefs.

Religious beliefs and the marital relationship: Arrow $2 A$

Correlations between religious beliefs and various aspects of marriage are complex and somewhat mixed (cf. Dollahite et al., 2004; Koenig et al., 2001). Even so, there are some recurring findings that warrant our attention here. Arrow 2A, which links the dimension of religious beliefs with the fathermother (F-M) marital relationship, represents research correlating religiosity with increased marital satisfaction and duration, and increased commitment and fidelity (Bahr \& Chadwick, 1985; Thomas \& Cornwall, 1990). In a more recent study, Call and Heaton (1997) similarly found that several aspects of shared religious experience were related to marital stability. Three additional qualitative studies examining factors in "successful long-term marriages" (defined as satisfying marriages of 25,30 , or $35+$ years, depending on the study) found that religious faith and/or beliefs were one of the top five facilitative factors reported by the participants (Kaslow \& Robinson, 1996; Robinson, 1994; Robinson \& Blanton, 1993). 
Some reports linking religious belief with other aspects of marriage are negative, however. Sullivan (2001) found that religiosity seemed to promote marital satisfaction when husbands were in good mental health but also found that religiosity may contribute to or exacerbate relationship problems when psychological functioning was problematic. Similarly, Arterburn and Felton (2001) present several clinical case studies where certain religious beliefs they refer to as "toxic faith" were expressed in damaging and sometimes extreme behaviors and views that harmed marital and family relationships. Further, Hathaway-Clark (1980) found that battered women are often highly religious and concluded that certain beliefs (e.g., tolerance of abuse) frequently contributed to the ongoing victimization of these women. In contrast, however, two recent studies with large samples found no relationship between conservative Protestantism and domestic violence (Ellison \& Anderson, 2001; Ellison, Bartkowski \& Anderson, 1999).

Religious beliefs and the mother-child relationship: Arrow $2 B$

Empirical publications linking religious beliefs and the mother-child relationship include the work of Bao and colleagues (1999) that indicates mothers in more positive mother-child relationships are more likely to transmit their religious beliefs to their adolescent children, while another study by Miller, Warner, Wickramaratne, and Weissman (1997) concludes, "Maternal religiosity and offspring concordance with it may protect against depression in offspring" (p. 1416).

Several studies address parent-child belief transmission and many of these indicate that mothers are influential in religious socialization (Acock \& Bengston, 1978; Clark, Worthington, \& Danser, 1988; Kieren \& Munroe, 1987). However, the emphasis of these studies is typically on transmission, not on the meaning and influence of religious beliefs in the mothers' lives or on the impact these beliefs have on maternal practices. Examples of scholarship that do delve into religious belief and motherhood include Kaufman's (1991) $R a$ chel's Daughters, which qualitatively examines Orthodox Jewish women (cf. Davidman, 1991) and Stacey and Gerard's (1990) study of Evangelical Christian women. Unfortunately, such studies are rare.

Religious beliefs and the father-child relationship: Arrow $2 C$

The connection between the dimension of religious beliefs and the father-child (F-C) relationship has been addressed by early studies correlating some religious beliefs with lower paternal absence rates and increased paternal devotion (Fichter, 1962), and recent work linking religious beliefs with higher levels of generativity and commitment to children (Christiansen \& Palkovitz, 1998), and increased paternal involvement (Bartowski \& $\mathrm{Xu}, 2000$; Wilcox, 1999, 2002). A recent related study by King (2003) examines religiousness in 
connection with eight aspects of father involvement among both married and divorced fathers and concludes that the

influence of religiousness on father involvement is generally modest and should not be overstated.... Nevertheless, certain aspects of father involvement are more frequent among the more religious, including better quality relationships... and stronger feelings of obligation for contact with children (p. 392).

While the above studies all link religious belief to aspects of responsible fathering, there may be a darker side to this connection as well. It has been posited that religious parents, especially conservative Protestant fathers, may be more authoritarian (low warmth, high control) than others in their parenting style since this is what some religious leaders advocate (cf. Ellison, Bartkowski, \& Segal, 1996).

A survey of the literature indicates mixed results regarding the linkage between conservative religiosity and parenting beliefs, especially fathers' beliefs. Laythe, Finkel, Bringle, and Kirkpatrick (2002) indicate that Christian orthodoxy is positively correlated with authoritarian attitudes, however, King (2003) reports that religious fathers who carry "traditional" beliefs concerning marriage and family are "more likely to espouse egalitarian statements about sharing housework and child care equally with their wives" (p. 390). Further, studies by Wilcox (1998) and Gunnoe, Hetherington, and Reiss (1999) link religiosity predominantly with authoritative (high warmth, high control) parenting, while aspects of authoritarianism were negatively correlated with religiosity. In another study, Wilcox (1999) found that Evangelical Christian fathers were more "traditional" (e.g., in expectations of obedience by children) but were also relatively highly involved fathers and "more expressive than most fathers" (p. 236).

To summarize, empirical research on the religious beliefs-fathering linkage has produced a profile that combines elements of authoritarian and authoritative parental typologies. More specifically, data indicate that religiously conservative fathers tend to be authoritarian in some of their attitudes and in expectations of obedience from their children but also indicate that these same fathers are often authoritative in terms of the high parental warmth and the love they reportedly express to their children.

In connection with clinical application, Wright, Watson, and Bell (1996) have conceptualized beliefs as fundamental in understanding ourselves and others and in healing troubled family relationships. For many individuals and families, religious beliefs are central to other beliefs they hold, particularly those regarding families. Subsequently, clinicians who are sensitive to beliefs (including religious beliefs) held by their clients are likely able to gain a more comprehensive understanding of the client and/or family. This idea is valid whether a client is atheistic, highly committed to 
a particular faith, or somewhere in between. For example, a client or family's spiritual and religious beliefs regarding divorce, sexuality, and death are often of pragmatic significance in conjunction with therapeutic issues and warrant the clinician's awareness, sensitivity, and consideration (Dollahite, Marks, \& Olson, 2002; Marks, 2004). My focus now turns from the cognitive dimension of religious beliefs to the social dimension of the religious community.

\section{Religious community and the marital relationship: Arrow $3 A$}

The connection between the dimension of religious community and the fathermother (F-M) spousal relationship is illuminated by Bahr and Chadwick's (1985) review that found

evidence that religious affiliation and activity have a modest positive impact on marriage and family life. . . To be precise, of the 17 [related] studies published between 1938 and 1980, 13 reported a direct, positive relationship between religiosity and marital satisfaction. (pp. 410-411, emphasis added).

The linkage of marital benefits with shared religious activity and involvement (not merely affiliation) is a prominent theme in more recent literature (Call \& Heaton, 1997; Curtis \& Ellison, 2002). Larson and Goltz (1989) similarly found that religious participation is correlated with higher commitment to marriage and increased family satisfaction.

Most of the research data linking involvement in a religious community with marital benefits are, however, based on same faith marriages. This is a vital point in light of Bahr's (1981, p. 260) finding that "same faith marriages are much more stable than interfaith marriages," a finding corroborated by Lehrer and Chiswick (1993). Indeed, shared religious commitments that reportedly help bind marriages may produce tension and conflict when unshared (Curtis \& Ellison, 2002). This seems particularly true of faiths that require significant investment of time and money. For example, Lehrer and Chiswick (1993) found that Latter-day Saint (LDS, Mormon) inter-faith marriages are three times more likely to end in divorce than LDS-to-LDS marriages (cf. Dollahite \& Marks, 2006).

Another important point rarely made explicit in the research linking religious involvement with marital and family satisfaction is that most American religions are highly marriage and family oriented. Therefore, some apparent "influences" of religion may be effects of self-selection (e.g., marriage-centered persons may be more likely to attend worship services), illustrating the need for work that examines the influences, factors, and meanings behind recurring correlations (Dollahite et al., 2004). Notably, a 12year longitudinal study by Booth, Johnson, Branaman, and Sica (1995) indicates that marital satisfaction frequently precedes religious involvement. 
Reciprocally, however, religious involvement often influences marriage as well (for reviews, see Christiano, 2000; Dollahite et al., 2003; Mahoney et al., 2001).

Religious community and the mother-child relationship: Arrow $3 B$

Women attend religious services far more frequently than men (Koenig et al., 2001) and the religious community has long been an important resource for American women (Ozorak, 1996). In a finding that links church attendance with social support, Ellison and George (1994) note that

Frequent attenders at religious services have larger nonkin networks than do infrequent church attenders or unchurched persons...[and] frequent churchgoers benefit from a wider array of supportive transactions than do their less religious counterparts, including instrumental support (i.e. money, goods, and services) and socioemotional support (p. 57).

While social support from the faith community is a valuable resource for many mothers, marital status seems to influence whether (or at least how much) mothers are supported by the faith community. Sorenson, Grindstaff, and Turner's (1995) study of depression in unmarried adolescent mothers found that young single mothers who were not religiously involved reported the lowest levels of depression, while the combination of religious involvement and non-marital motherhood was stressful for significantly religious young women. Additionally, Sorenson and colleagues found that "even greater distress [was] experienced by young women who lived in an unmarried relationship while at the same time taking part in religious activities" (p. 80). By way of contrast, religiosity was not related to depression among religiously involved, married, teen mothers.

A second example of the importance of maternal marital status in the faith community may be drawn from the work of Taylor and Chatters (1988) who found that divorced and separated women tend to receive less social support from their faith communities than do widows. Findings like these contextualize a Dollahite et al. (2004) conclusion that a "key challenge for [many] American churches in the $21^{\text {st }}$ century will be to find a balance between supporting the standard of marriage-based families that are idealized...while addressing the pluralistic family realities that confront them" (p. 414).

Religious community and the father-child relationship: Arrow 3C

The connection between religious community and the father-child (F-C) relationship has received recent attention from an array of researchers, family professionals, and policy makers. A central theme in some of this work is that American fatherhood is declining as evidenced by high divorce and nonmarital birth rates and that faith communities are in a unique position to 
ameliorate these trends (Eberly, 1999; Horn, 2001). Research has indicated that active church attendance correlates with lower rates of unwed teen paternity in one sample (Hendricks, Robinson-Brown, \& Gray, 1984) and with warm, affectionate parenting in another (Bartowski \& Xu, 2000). Nock's (1998) work emphasizes that a man is known and respected in his religious community for filling his responsibilities, including his responsibilities to his child (ren). In another recent study of religion and father involvement, Wilcox (2002) concludes that “religion does play a role in shaping men's commitments to their children" and then adds:

at least in terms of the quantity of their involvement, conservative Protestant and Catholic residential fathers are more likely to embody the new [involved] fatherhood style Furstenberg attributes to Good Dads (p. 791).

In an earlier study, Wilcox (1999) also found that "religious affiliation, particularly an Evangelical Protestant affiliation, was a much stronger predictor of fatherhood conduct than were gender role attitudes" (p. 235), indicating the influence faith may have.

Marsiglio et al. (2000) address the religious community as a social support in fathering and emphasize that fathers "contribute to their children's development through their connections with other individuals and organizations" and mention "churches" as one of the contexts where "social capital is created" (p. 1176). Specifically, the social connections that religious communities facilitate are helpful in creating opportunities, including employment and networking opportunities, for all family members.

Continuing on the social network theme, a qualitative study by Dollahite et al. (1998) found that "help from the church" was a primary resource that highly involved fathers of children with special needs relied on as they tried to meet both the everyday and extraordinary needs of their children (p. 77). In a follow-up study that explored this finding in more depth, fathers gave specific narrative accounts of how their religious communities had offered social, emotional, spiritual, financial, and temporal support (including transportation and housing) in times of need. Conversely, when the fathers' religious communities failed them "it was both disappointing and hurtful in ways that seemed to elicit deeper frustration and pain than failures by secular agencies and institutions" (Marks \& Dollahite, 2001, p. 636). Faith communities do influence some fathers but this influence can be positive, negative, or both (cf. Palkovitz \& Palm, 1998).

In terms of clinical application, the multi-faceted help systems inherent in many communities of faith may beneficially augment a variety of clinical interventions through the provision of social, emotional, and temporal support. Additionally, religious communities offer opportunities to serve others that can foster a sense of meaning and connection (Dollahite \& Marks, 2005; Marks, 2004). From a systems perspective, clinicians would benefit by 
knowing if and how a religious community supports a client and their family, or if this community might be exacerbating focal problems.

\section{Summary}

Religious practices are reportedly beneficial to marriage and parent-child relationships for many families and individuals, but compulsory family worship may have ill effects. Women engage in religious practices more frequently than men and are more likely to be "religious" but men who are religiously involved tend to be influenced more by religion than women, relative to nonreligious persons of the same gender. A key regarding the dimension of religious practices is a sense of connection, sacredness, and or transcendence is most salient for family members.

Religious beliefs are reportedly influential in promoting long-term marriage, marital satisfaction, and marital quality when shared but there is some evidence that indicates religious beliefs may be more bane than boon in the context of inter-faith marriages. Additionally, certain "toxic" religious beliefs may contribute to abuse and tolerance of abuse in marriage. Relatively little is empirically substantiated regarding the religious beliefmothering connection, although maternal religiosity has been correlated with less depression in children. Certain religious beliefs of fathers are related to warm, responsible fathering but authoritarianism has also been correlated with some beliefs.

Religious community is correlated with marital stability and quality when couples are actively involved together but religious affiliation alone is insignificant in most studies. Religious community is a major support and resource for many married and widowed mothers but is generally less supportive of divorced and never-married mothers and may even add to the stress of those in the latter context. The faith community-fathering connection holds intense interest at present, with some research linking certain aspects of religious involvement with responsible fathering. However, the abuse of religion by domineering fathers remains a concern. As stated earlier in this paper, future research efforts will investigate both healthy and unhealthy linkages between different dimensions of religion and family relationships.

\section{Conclusion}

In this paper I have illustrated that three dimensions of religion have been frequently correlated with healthier intergenerational and marital relationships. A critical point, however, is that depth is not a characteristic of most religion-family research and work exploring the hows, whys, meanings, and processes behind these religion and family correlations (including both "healthy" and "unhealthy" connections) is needed. Additionally, future research needs to become more pluralistic in at least four ways by examining: 
(a) a variety of family forms, (b) more families of color, (c) non-Christian world faiths (particularly Islam and Judaism), and (d) inter-faith families. Data in these content areas will strengthen the religion-family knowledge base while also allowing us to revisit previous data from white, nuclear, Christian, samefaith families in a new comparative light. Careful, moderate, balanced scholarship in this area is desperately needed to counter popular media that tend to accentuate extremes.

A scholarly dialogue without rigorous empirical research and thoughtful and challenging theoretical discussion on religion and intergenerational relationships is inevitably a poorer one. Conversely, the knowledge base will be fortified and enhanced by pluralistic religion-family research that moves beyond recurring correlations to examine critical whys, hows, meanings, and processes through quantitative and qualitative approaches.

\section{References}

Acock, A. and Bengtson, V. (1978). On the relative influence of mothers and fathers: A covariance analysis of political and religious socialization. Journal of Marriage and the Family, 40, 519-531.

Arterburn, S. and Felton, J. (2001). Toxic Faith. Colorado Springs, CO: Waterbrook.

Bahr, H.M. (1981). Religious intermarriage and divorce in Utah and the mountain states. Journal for the Scientific Study of Religion, 20, 251-261.

Bahr, H.M. and Chadwick, B.A. (1985). Religion and family in Middletown, USA. Journal of Marriage and the Family, 47, 407-414.

Bao, W, Whitbeck, L.B., Hoyt, D.R., and Conger, R.D. (1999). Perceived parental acceptance as a moderator of religious transmission among adolescent boys and girls. Journal of Marriage and the Family, 61, 362-372.

Bartowski, J.P. and Xu, X. (2000). Distant patriarchs or expressive dads?: The discourse and practice of fathering in Conservative Protestant families. The Sociological Quarterly, 41, 465485.

Booth, A., Johnson, D.R., Branaman, A., and Sica, A. (1995). Belief and behavior: Does religion matter in today's marriage? Journal of Marriage and the Family, 57, 661-671.

Boyatzis, C.J. and Janicki, D.L. (2003). Parent-child communication about religion: Survey and diary data on unilateral transmission and bi-directional reciprocity styles. Review of Religious Research, 44, 252-270.

Call, V.A. and Heaton, T.B. (1997). Religious influence on marital stability. Journal for the Scientific Study of Religion, 36, 382-392.

Christiano, K. (2000). Religion and the family in modern American culture. In S. Houseknecht, and J. Pankhurst (Eds.). Family, Religion, and Social Change in Diverse Societies (pp. 43-78). New York: Oxford.

Christiansen, S.L. and Palkovitz, R. (1998). Exploring Erikson's psychosocial theory of development: Generativity and its relationship to paternal identity, intimacy, and involvement in childcare. The Journal of Men's Studies, 7, 133-156.

Clark, C.A., Worthington, E.L., and Danser, D.B. (1988). The transmission of religious beliefs and practices from parents to firstborn early adolescent sons. Journal of Marriage and the Family, 50, 463-472.

Curtis, K.T. and Ellison, C.G. (2002). Religious heterogamy and marital conflict. Journal of Family Issues, 23(4):551-576.

Davidman, L. (1991). Tradition in a Rootless World: Women Turn to Orthodox Judaism. Berkeley CA: University of California Press.

Doherty, W.J. (2001). Take Back Your Marriage. New York: Guilford Press. 
Doherty, W.J. (2002). The Intentional Family: Simple Rituals to Strengthen Family ties. New York: Quill.

Dollahite, D.C. (2003). Fathering for eternity: Generative spirituality in Latter-day Saint fathers of children with special needs. Review of Religious Research, 44, 339-351.

Dollahite, D.C. (1998). Origins and highlights of the special issue on fathering, faith, and spirituality. The Journal of Men's Studies, 7, 1-2.

Dollahite, D.C. and Marks, L.D. (2005). How highly religious families strive to fulfill sacred purposes. In: V. Bengtson, P. Dillworth-Anderson, D. Klein, A. Acock, and K. Allen (Eds.), Sourcebook of Family Theory and Research (pp. 533-541). Thousand Oaks CA: Sage.

Dollahite, D.C. and Marks, L.D. (2006). Family and community nurturing spirituality in Latterday Saint children and youth. In K. Yust, A.N. Johnson, S.E. Sasso, and E.C. Roehlkepartain (Eds.), Religious Perspectives on Spirituality in Childhood and Adolescence. Lanham, MD: Rowman \& Littlefield.

Dollahite, D.C., Marks, L.D., and Goodman, M. (2004). Religiosity and families: Relational and spiritual linkages in a diverse and dynamic cultural context. In M. Coleman and L.H. Ganong (Eds.), The Handbook of Contemporary Families: Considering the Past, Contemplating the Future (pp. 411-431). Thousand Oaks, CA: Sage.

Dollahite, D.C., Marks, L.D., and Olson, M.M. (1998). Faithful fathering in trying times: Religious beliefs and practices of Latter-day Saint fathers of children with special needs. The Journal of Men's Studies, 7, 71-94.

Dollahite, D.C., Marks, L.D., and Olson, M.M. (2002). Fathering, faith, and family therapy: Generative narrative therapy with religious fathers. Journal of Family Psychotherapy, 13, 263-294.

Eberly, D.E. (Ed.) (1999). The Faith Factor in Fatherhood (pp. 219-240). New York: Lexington.

Eliade, M. (1959). The Sacred and the Profane: The Nature of Religion. New York: Harcourt Brace Jovanovich.

Ellis, A. (1986). The case against religion: A psychotherapist's view and the case against religiosity. Austin: American Atheist Press.

Ellison, C.G. and Anderson, K.L. (2001). Religious involvement and domestic violence among U.S. couples. Journal for the Scientific Study of Religion, 40, 269-286.

Ellison, C.G., Bartkowski, J.P., and Anderson, K.L. (1999). Are there religious variations in domestic violence?. Journal of Family Issues, 20, 87-113.

Ellison, C.G., Bartkowski, J.P., and Segal, M.L. (1996). Conservative Protestantism and the parental use of corporal punishment. Social Forces, 74, 1003-1028.

Ellison C.G. and George, L.K. (1994). Religious involvement, social ties, and social support in a southeastern community. Journal for the Scientific Study of Religion, 33, 46-61.

Fichter, J.H. (1962). Religion and socialization among children. Review of Religious Research, 4, 24-33.

Fiese, B.H. and Tomcho, T. J. (2001). Finding meaning in religious practices: The relation between religious holiday rituals and marital satisfaction. Journal of Family Psychology, 15, 597-609.

Freud, S. (1927). The future of an illusion. Garden City, NY: Doubleday.

Gunnoe, M.L., Hetherington, E.M., and Reiss, D. (1999). Parental religiosity, parenting style, and adolescent social responsibility. Journal of Early Adolescence, 19, 199-225.

Hathaway-Clark, C. (1980, April). Multidimensional locus of control in battered women. Paper presented at the Rocky Mountain Psychological Association, Tucson, AZ.

Hendricks, L.E., Robinson-Brown, D.P., and Gray, L.E. (1984). Religiosity and unmarried black adolescent fatherhood. Adolescence, 19, 417-424.

Hertel, B.R. and Donahue, M.J. (1995). Parental influences on god images among children: Testing Durkheim's metaphoric parallelism. The Journal for the Scientific Study of Religion, 34, 186-199.

Horn, W.F. (2001). Turning the hearts of the fathers: Promoting fatherhood through faith. In: J. Fagan and A.J. Hawkins (Eds.), Clinical and Educational Interventions with Fathers. New York: Haworth.

Imber-Black, E. and Roberts, J. (1993). Rituals for our Times: Celebrating, Healing, and Changing our Lives and Relationships. New York: HarperPerennial.

Imber-Black, E., Roberts, J., and Whiting, R.A. (Eds.) (1988). Rituals in Families and Family Therapy. New York: Norton. 
Kaslow, F. and Robinson, J.A. (1996). Long-term satisfying marriages: Perceptions of contributing factors. American Journal of Family Therapy, 24, 154-170.

Kaufman, D R. (1991). Rachel's daughters: Newly Orthodox Jewish women. NJ: Rutgers: New Brunswick.

Kieren, D.K. and Munro, B. (1987). Following the leaders: Parents' influence on adolescent religious activity. Journal for the Scientific Study of Religion, 26, 249-255.

King, V. (2003). The influence of religion on fathers' relationships with their children. Journal of Marriage and Family, 65, 382-395.

Koenig, H.G., McCullough, M.E., and Larson, D.B. (2001). Handbook of religion and health. New York: Oxford University Press.

Larson, L.E. and Goltz, J.W. (1989). Religious participation and marital commitment. Review of Religious Research, 30, 387-400.

Laythe, B., Finkle, D.G., Bringle, R.G., and Kirkpartick, L.A. (2002). Religious fundamentalism as a predictor of prejudice: A two-component model. Journal for the Scientific Study of Religion, 41, 623-635.

Lee, J.W., Rice, G.T., and Gillespie, V.B. (1997). Family worship patterns and their correlation with adolescent behavior and beliefs. Journal for the Scientific Study of Religion, 36, 372-381.

Lehrer, E.L. and Chiswick, C.U. (1993). Religion as a determinant of marital stability. Demography, 30, 385-403.

Mahoney, A., Pargament, K.I., Jewell, T., Swank, A.B., Scott, E., and Emery, E. et al. (1999). Marriage and the spiritual realm: The role of proximal and distal religious constructs in marital functioning. Journal of Family Psychology , 13, 321-338.

Mahoney, A., Pargament, K.I., Murray-Swank, A., and Murray-Swank, N. (2003). Religion and the sanctification of family relationships. Review of Religious Research, 44, 220-236.

Mahoney, A., Pargament, K.I., Tarakeshwar, N., and Swank, A.B. (2001). Religion in the home in the 1980s and 90s: A meta-analytic review and conceptual analyses of links between religion, marriage and parenting. Journal of Family Psychology, 15, 559-596.

Marks, L.D. (2005). Religion and bio-psycho-social health: A review and conceptual model. Journal of Religion and Health, 44, 173-186.

Marks, L.D. (2004). Sacred practices in highly religious families: Christian, Jewish, Mormon, and Muslim perspectives. Family Process.

Marks, L.D. and Dollahite, D.C. (2001). Religion, relationships, and responsible fathering in Latter-day Saint families of children with special needs. Journal of Social and Personal Relationships, 18, 625-650.

Marx, K. and Engels, F. (1964). On Religion. New York: Schocken Books. Undated Scholars Press Reprint.

Marsiglio, W., Amato, P., Day, R.D., and Lamb, M.E. (2000). Scholarship on fatherhood in the 1990s and beyond. Journal of Marriage and the Family, 62, 1173-1191.

Miller, L., Warner, V., Wickramaratne, P., and Weissman, M. (1997). Religiosity and depression: Ten-year follow-up of depressed mothers and offspring. Journal of the American Academy of Child and Adolescent Psychiatry, 52, 41-49.

Miller, W.R. and Thoresen, C.E. (2003). Spirituality, religion, and health: An emerging research field. American Psychologist, 58, 24-35.

Nock, S.J. (1998). Marriage in Men's Lives. New York: Oxford University Press.

Ozorak, E.W. (1996). The power but not the glory: How women empower themselves through religion. Journal for the Scientific Study of Religion, 35(1):17-29.

Palkovitz, R. (2002). Involved Fathering and Men's Adult Development: Provisional Balances. Hillsdale, NJ: Erlbaum.

Palkovitz, R. and Palm, G. (1998). Fatherhood and faith in formation: The developmental effects of fathering on religiosity, morals, and values. The Journal of Men's Studies, 7, 33-52.

Pearce, L.D. and Axinn, W.G. (1998). The impact of family religious life on the quality of motherchild relations. American Sociological Review, 63, 810-828.

Robinson, L.C. (1994). Religious orientation in enduring marriages: An exploratory study. Review of Religious Research, 35, 207-218.

Robinson, L.C. and Blanton, P.W. (1993). Marital strengths in enduring marriages. Family Relations, 42, 38-45.

Snarey, J.R. and Dollahite, D.C. (2001). Varieties of religion-family linkages. Journal of Family Psychology, 15, 646-651. 
Sorenson, A.M., Grindstaff, C.F., and Turner, R.J. (1995). Religious involvement among unmarried adolescent mothers: A source of emotional support? Sociology of Religion, 56, 71-81.

Stacey, J. and Gerard, S.E. (1990). "We are not doormats": The influence of feminism on contemporary Evangelicalism in the United States. In: F. Ginsburg and A. Tsing (Eds.), Negotiating Gender in American Culture. Boston: Beacon.

Stark, R. (1971). Psychopathology and religious commitment. Review of Religious Research, 12 , 165-176.

Stark, R. and Bainbridge, W. (1996). A Theory of Religion. New Brunswick, NJ: Rutgers.

Sullivan, K.T. (2001). Understanding the relationship between religiosity and marriage: An investigation of the immediate and longitudinal effects of religiosity on newlywed couples. Journal of Family Psychology, 15, 610-626.

Taylor, R.J. and Chatters, L.M. (1988). Church members as a source of informal social support. Review of Religious Research, 30, 193-203.

Thomas, D.L. and Cornwall, M. (1990). Religion and family in the 1980s: Discovery and development. Journal of Marriage and the Family, 52, 983-992.

Vergote, A. (1980). Religion after the critique of psychoanalysis. The Annual Review of the Social Sciences of Religion, 4, 1-29.

Wilcox, W.B. (1998). Conservative protestant childrearing: Authoritarian or authoritative?. American Sociological Review, 63, 796-809.

Wilcox, W.B. (1999). Emerging attitudes about gender roles and fatherhood. In D. E. Eberly (Ed.), The Faith Factor in Fatherhood (pp. 219-240). New York: Lexington.

Wilcox, W.B. (2002). Religion, convention, and parental involvement. Journal of Marriage and Family, 64, 780-792.

Wright, L.M., Watson, W.L., and Bell, J.M. (1996). Beliefs: The Heart of Healing in Families and Illness. New York: Basic.

Wuthnow, R. (1999). Growing up Religious: Christians and Jews and their Journeys of Faith. Boston: Beacon. 